\title{
A SEGREGAÇÃO SOCIAL DO CABOCLO DE PORTO NOVO A PARTIR DA ANÁLISE DA PAISAGEM ${ }^{1}$
}

\author{
Patrício Reichert ${ }^{2}$
}

\section{Resumo}

A antiga colônia Porto Novo, localizada no extremo oeste de Santa Catarina, colonizada a partir de 1926 sob a liderança de jesuítas alemães de São Leopoldo - RS caracterizou-se como um projeto de colonização étnico e religiosamente homogêneo: católicos e alemães. A população cabocla, uma minoria étnica no atual território, sempre marcou presença na ocupação e formação da colônia. Algumas famílias caboclas já viviam no local antes da vinda de colonos, outras foram atraídas pelos serviços que o projeto da colonização lhes podia oferecer. A terra lhes foi negada por não terem incorporado a concepção da propriedade privada e por não se enquadrarem nas características étnicas e religiosas idealizadas pelo projeto da colonização. Historicamente o caboclo sofreu uma segregação social, tanto econômica quanto racial. Uma segregação que atualmente pode ser observada a partir da análise da paisagem do espaço rural e urbano. No meio rural as famílias caboclas aglutinamse em aglomerados, concentram-se em áreas mais inóspitas, ou, vivem isolados na condição de agregados ou proprietários de pequenos terrenos que não lhes garante a subsistência. No meio urbano concentram-se nos bairros mais periféricos e sobrevivem na informalidade do trabalho temporário.

Palavras - chave: paisagem, caboclo, segregação social, espaço urbano, espaço rural.

\begin{abstract}
The old Porto Novo colony located at the far west of Santa Catarina (Brazil), settled in 1926 under the leadership of German Jesuits from São Leopoldo - Rio Grande do Sul (Brazil), characterized as a project of ethnic colonization and religiously homogeneous: Catholics and Germans. The caboclo population (of mixed race from white, Indian and black), an ethnic minority in the current territory, always have set presence of the occupations and colony formation. Some caboclas families have been already living there before the coming of settlers, others were attracted by the services that the project of colonization could offer them.

\footnotetext{
${ }^{1}$ Este artigo faz parte do resultado da minha pesquisa de mestrado. REICHERT, Patrício. Diferenças culturais entre caboclos e teuto-brasileiros de Porto Novo: a segregação social do caboclo. Porto Alegre: UFRGS, 2008, p. $179-239$.

2 Professor de geografia do ensino fundamental do município de Feliz/RS. E-mail: patricioort@yahoo.com.br
} 
The land was denied because they haven't incorporated the conception of private property and they did not fit the ethnic and religious devised by the project of colonization. Historically, the caboclo suffered a social segregation, both economically and racially. A segregation that currently can be seen from the analysis of the rural and urban landscape. In rural areas caboclas families coalesce into clusters, concentrated in the most inhospitable areas, or live in isolated condition of households or owners of small plots that do not guarantee subsistence. Urban areas are concentrated in the peripheral neighborhoods and survive in the informal temporary work.

Keywords: landscape, caboclo, segregation, urban space, rural space.

\section{Introdução}

As características sócio-culturais do caboclo $^{3}$ foram pouco atrativas às instâncias políticas de escala nacional e estadual que por meio do processo político da colonização pretendiam modernizar o Estado com a sua maior integração ao grande capital internacional. $\mathrm{Na}$ estratégia de dinamizar as relações capitalistas sobre o território a partir da pequena propriedade agrícola, privada e produtiva, idolatraram-se as virtudes do camponês europeu que com a sua imigração ao Brasil já traria os princípios da propriedade privada e das relações capitalistas de trabalho. Sem se comprometer com algum amparo social sobre o camponês colono e caboclo, o Estado terceirizou os serviços de colonização a grandes corporações capitalistas cedendo-lhes vastas áreas de terras. Estas corporações em geral novamente subdividiam as terras que legalmente lhes pertenciam e as comercializavam a empresas de colonização, que por sua vez efetivavam a ocupação da área por colonos com a venda dos lotes agrícolas. Os camponeses caboclos não tendo a incorporação de valores capitalistas, como a concepção da propriedade privada da terra e a produção de excedentes com a idéia de acúmulo, deixaram de ser incluídos nos projetos de colonização que se desenvolviam a partir da especulação do mercado da terra. O Estado não se preocupou em elaborar um projeto específico capaz de integrar as características camponesas em espaços territoriais nas quais as comunidades caboclas pudessem se apropriar legalmente. "Fundamentado na ideologia da igualdade, a cultura política ocidental enxerga a diferença como uma ameaça, uma antinomia, arriscando a afundá-la numa crise de identidade”. (SEMPRINI, 1999, p. 159). Ao tratar de

\footnotetext{
3 O caboclo nesta pesquisa é caracterizado pela sua identidade camponesa a partir da mestiçagem com branco, índio e negro no Brasil meridional.
} 
forma homogênea ${ }^{4}$ as diferenças da identidade camponesa cabocla e teuto-brasileira, deixando ambas a mercê da exploração das companhias de colonização que usufruíram da renda capitalizada da terra a partir da sua comercialização, contribuiu para a segregação social do caboclo que a partir das suas características culturais não se apresentava tão apto como o colono na disputa seletiva dos espaços sociais dentro de uma lógica racional capitalista.

Os colonos, para não se encontrarem abandonados a própria sorte devido à isenção do Estado no oferecimento de qualquer tipo de assistência social, organizaram-se socialmente com relativa autonomia a partir das suas tradicionais comunidades camponesas, buscando a sua identificação na etnia e na religião. Os caboclos, além de ser praticamente impossibilitada do acesso a propriedade privada, foram rejeitados nas relações sociais das comunidades que se construíram a partir de um ideal étnico e religioso. $\mathrm{Na}$ medida em que os colonos ocupavam os seus lotes, os caboclos adentravam na mata onde se estabeleciam em seus ranchos improvisados até que fossem novamente alcançados pela institucionalização da propriedade privada.

A modernização agrícola a partir da década de 70 aniquilou a maior parte da mão-deobra cabocla, reduzindo ao extremo as tradicionais relações trabalhistas com os colonos, como às diárias, as empreitadas ou a condição de morador aos fundos de uma propriedade. Expulsou do meio rural grande parte desta população que até então havia resistido à imposição da propriedade privada se adaptando a novas formas de trabalho. Os caboclos, que em geral não se adaptaram ao modelo hegemônico da política da colonização e nem da posterior modernização agrícola, atualmente encontram-se em extrema exclusão do meio social vigente.

No antigo território de Porto Novo, há uma visível segregação social dos caboclos em decorrência das suas condições econômicas e devido aos preconceitos em relação a sua herança cultural e racial. A segregação é possível de ser observada tanto na paisagem ${ }^{56}$ quanto nas relações sociais que envolvem o cotidiano da vida comunitária.

\footnotetext{
$4 \quad$ Além do Estado não promover nenhum projeto específico de acesso do caboclo a terra, defendeu teorias preconceituosas e racistas em relação a sua identidade cultural, bem como utilizou a força repressiva policial e militar na expulsão do caboclo das suas posses.

Nesta pesquisa entende-se como território de Porto Novo a área delimitada pelo projeto de colonizição, na qual há a supremacia teuto-brasileira com frágeis territorialidades caboclas.

6 Será utilizado o conceito de Brunet apud Claval (2004, p. 48): “aquilo que o olho abarca [...] de uma só olhadela, o campo do olhar. A paisagem é, portanto, uma aparência e uma representação [...]. Só é paisagem quando percebida. Alguns de seus elementos não aguardaram a humanidade para existir, mas se compõem uma paisagem, é sob a condição de serem olhados. Somente a representação os faz paisagem”.
} 


\section{A paisagem denuncia a segregação social do caboclo}

Numa análise superficial, já é possível detectar a supremacia da identidade cultural teuto-brasileira nas paisagens que compõem o antigo território de Porto Novo. Monumentos, construções típicas, praças, placas, nomes de ruas e lugares memoram ou homenageiam os atos do colonizador, a cultura germânica e a influência jesuítica sobre o grupo étnico. A toponímia e a construção de monumentos transmitem significados simbólicos que trazem uma considerável contribuição para uma criação mítica sobre a origem do território com a finalidade de institucionalizá-lo e sacramentá-lo. (BONNEMAISON apud CLAVAL, 2001, p. 208).

No entender de Claval (Ibid., p. 202) “Nomear os lugares é impregná-los de cultura e de poder". Compreende-se assim, que a institucionalização de um território não se dá por um ato único, os valores culturais que o grupo dominante celebra precisam ser intensamente reproduzidos para continuar a ter significado. A toponímia e os monumentos históricos em grande parte cumprem esta função impregnando tais valores sutilmente no cotidiano da população. Mas os valores inscritos nas paisagens são ainda frequentemente reforçados em rituais festivos, religiosos ou em diferentes cerimônias públicas. Em Porto Novo, como principais exemplos podemos citar a Kerb (festa do padroeiro da comunidade), a Erntedankfest (festa em agradecimento a colheita), a comemoração do dia do colono e a Oktoberfest, que são rituais festivos e religiosos que relembram a saga, a fé e o altruísmo dos colonos. Estes rituais avigoram antigos valores culturais e uma identidade de grupo a partir de uma origem em comum. "Os ritos lembram o ato fundador e permitem o restabelecimento das condições originais, quando a prática cotidiana faz esquecê-las”. (Ibid., p. 210).

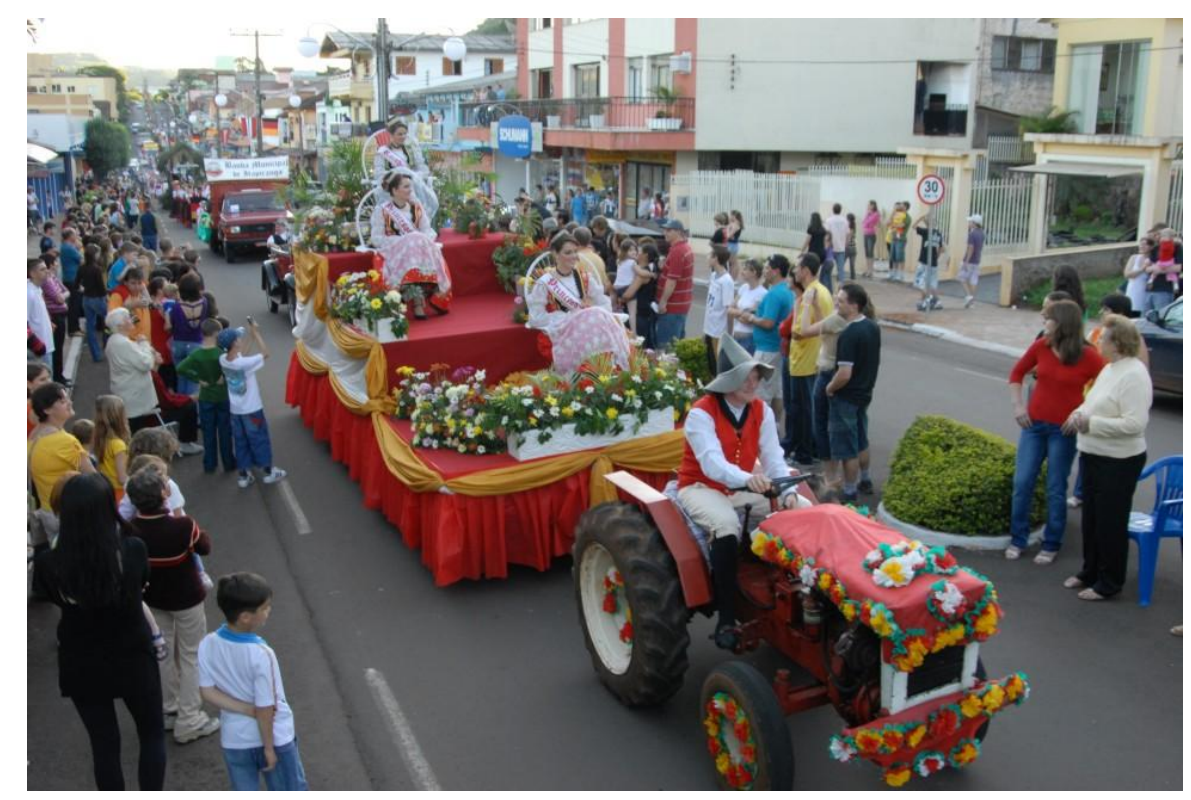


$\mathrm{Na}$ institucionalização do território por meio de ritos e signos, o grupo hegemônico cria facilmente um discurso em seu favor, reproduzindo continuadamente através das gerações uma história utilitarista (aquela história do vencedor e dos grandes feitos). Como por exemplo, nas paisagens de Porto Novo, não é possível encontrar monumentos ou topônimos que memorizam ou homenageiam a minoria étnica cabocla que teve (e ainda tem) uma significativa participação na construção do território.

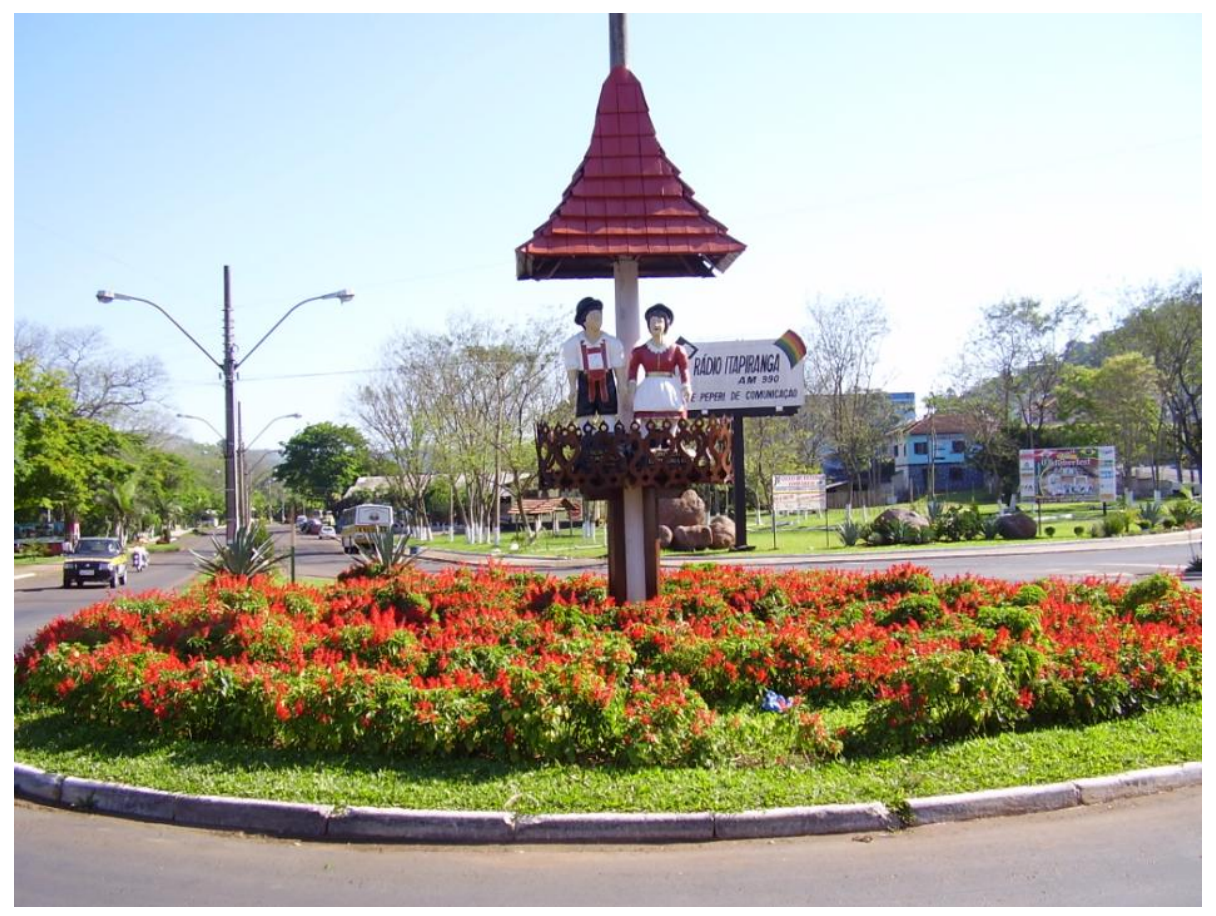

Figura 2: Monumento em homenagem à imigração alemã. Fonte: Patrício Reichert, 2006.

As paisagens trazem a marca das culturas, e ao mesmo tempo, as influenciam. É neste sentido que Berque (2004, p. 84 a 86) entende que a paisagem é uma marca e uma matriz. A paisagem não pode ser compreendida como um simples reflexo da cultura dentro da qual foi construída, sendo matriz "age como um sistema de criação de signos através do qual um sistema social é transmitido, reproduzido, experimentado e explorado”. (DUNCAN, 2004, p. 106). Os diversos valores culturais inscritos, geralmente de forma simbólica nas paisagens, atuam como instrumentos na reprodução da ordem social do grupo hegemônico, legitimando os seus discursos.

Em Porto Novo, se por um lado as paisagens revelam a supremacia da cultura teutobrasileira, por outro, não são capazes de ocultar a presença da cultura cabocla. Ao percorrer o 
território sob um olhar mais atento é possível observar que as paisagens denunciam a segregação social do caboclo, tanto no espaço rural quanto no urbano.

\section{A segregação social do caboclo a partir da análise da paisagem rural}

No meio rural as famílias caboclas encontram-se na condição de pequenos proprietários $^{7}$, arrendatários, parceiros ou posseiros. Concentram-se em aglomerados ${ }^{8}$ ou encontram-se dispersos em seus pequenos ranchos com suas unidades familiares. Ocupam as áreas mais impróprias para a prática agrícola, como os terrenos íngremes com solos pouco férteis e geralmente de difícil acesso.

7 Quase sempre com uma área inferior de um módulo agrícola que em Santa Catarina é de 3 ha.

8 Agrupamento contínuo de famílias caboclas dentro de uma pequena área de terras. 


\section{Localização da população cabocla rural de Porto Novo}

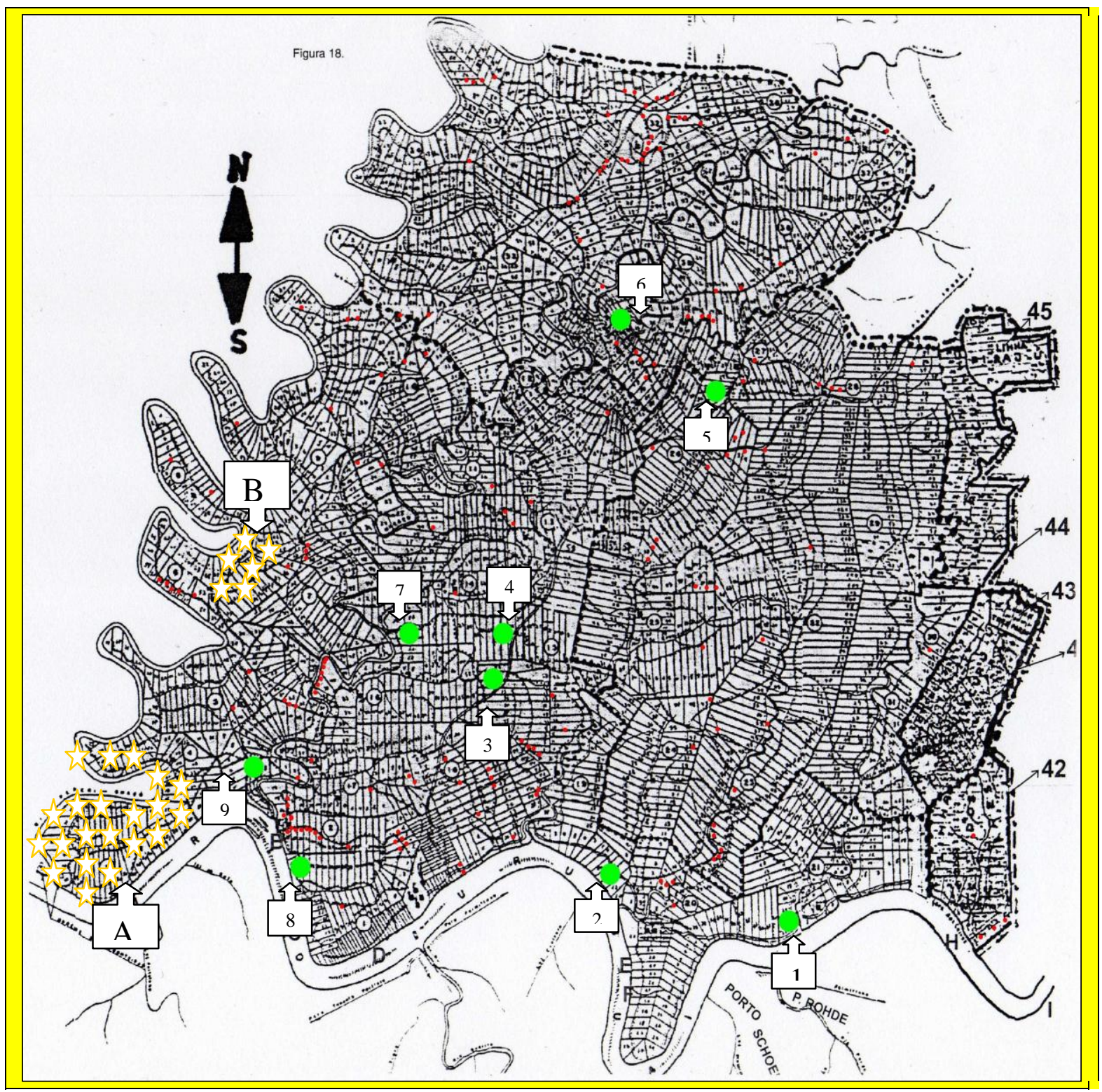

Legenda

Concentração de caboclos: área A (47 famílias caboclas e 23 mistas); área B (10 famílias caboclas e 7 mistas).

Aglomerados caboclos.

- Residência de famílias caboclas mais dispersas.

Figura 3: Fonte: Mapa produzido pelo autor com base no mapa de Jungblut (2004, p. 102); dados obtidos a partir das agentes municipais de saúde que atuam na área que compreende o antigo Porto Novo e da pesquisa in loco.

Para ter-se uma maior compreensão da situação social da população cabocla rural de Porto Novo será feita primeiramente uma análise a partir das paisagens nas quais as famílias se encontram em maior número, como nos aglomerados e nas áreas de concentração de caboclos, e posteriormente, as que se encontram mais dispersas. 


\subsection{Os aglomerados caboclos}

Os aglomerados caracterizam-se como um agrupamento de famílias caboclas dentro de um pequeno espaço de terra, que geralmente não ultrapassa 1,5 ha, e concentra em torno de três a nove famílias. Há a exceção de um aglomerado que é formado por 32 famílias e ocupa uma área de 65 ha. Na área pesquisada do antigo território de Porto Novo foram identificados nove aglomerados caboclos.

As áreas nas quais as famílias caboclas encontram-se agrupadas localizam-se em espaços íngremes, de difícil acesso e com solos impróprios para o cultivo agrícola. A maioria dos pequenos lotes ocupados pelos aglomerados foi adquirida por meio de contratos de compra de antigas propriedades de colonos. Geralmente um caboclo adquiriu um lote de terra e novamente o subdividiu a outras famílias caboclas. Dentro do aglomerado uma família possui apenas um documento legal da compra do terreno, enquanto que os demais adquiriram a demarcação de seus terrenos desta família através de uma relação de confiança, sem um documento legal. Ainda entre os aglomerados identificados, dois se formaram por meio da ocupação de espaços públicos: um à margem da rodovia SC 472 na comunidade de Cordilheira, e o outro, o maior de Porto Novo com 32 famílias, ocupou uma área de preservação permanente de 65 ha às margens do rio Uruguai e Macaco Branco na comunidade de Laranjeira.

As famílias dos aglomerados caboclos encontram-se em precárias condições de moradia. O acesso à energia elétrica foi apenas lhes dado em 2005 através do programa do governo federal "Luz para Todos". Moram em pequenas casas rústicas de madeira, onde não possuem água encanada e potável, e tem péssimas instalações sanitárias.

Grande parcela do rendimento econômico familiar destas famílias é oriunda da prestação de serviços temporários nas propriedades agrícolas dos colonos. Nas famílias onde há a aposentadoria de um idoso, esta passa a ser sua principal fonte de renda. A contribuição do assistencialismo público em algumas famílias é de fundamental importância, em especial a bolsa família. Em alguns aglomerados há caboclos que possuem um trabalho formal no espaço urbano, como operários da agroindústria Seara Alimentos $\mathrm{S} / \mathrm{A}^{9}$, nestes casos as famílias encontram-se estabelecidas em moradias um pouco melhor estruturadas.

$9 \quad$ Muitos caboclos têm dificuldades em se adaptar ao ritmo de trabalho da agroindústria e abandonam seu emprego. Outra grande parcela não consegue ingressar no trabalho formal do espaço urbano devido a baixa escolaridade, sem considerar ainda o preconceito que sofrem na hora de procurar por um emprego. 
Junto às residências, algumas famílias ainda mantêm tímidas atividades camponesas: criam um terneiro, um porco ou algumas galinhas; quando possível fazem um pequeno roçado onde cultivam alguns alimentos. Como não possuem espaço suficiente para cultivar o alimento necessário para o trato de seus animais e para o sustento das suas famílias, muitas vezes negociam a ração animal ou o alimento humano com um colono.

Em algumas situações, o convívio extremamente próximo e sem limites legalizados cria intensos conflitos entre as famílias. No entanto, a maioria dos aglomerados pode ser caracterizada como famílias extensas, na qual as unidades familiares possuem um laço de parentesco fortemente interdependente. Os limites dos terrenos de cada unidade familiar, muitas vezes não estão bem visíveis, e como os próprios caboclos explicam, usa-se o critério "do respeito".

Estas aglutinações de famílias caboclas podem ser compreendidas como aglomerados de exclusão num território historicamente destacado por sua homogeneidade étnica e religiosa: descendentes de alemães e católicos. Dentro deste território na qual o caboclo é segregado por fatores econômicos e étnicos, os aglomerados são espaços de refúgio, onde as famílias caboclas conseguem um pouco de conforto e proteção junto aos seus semelhantes.

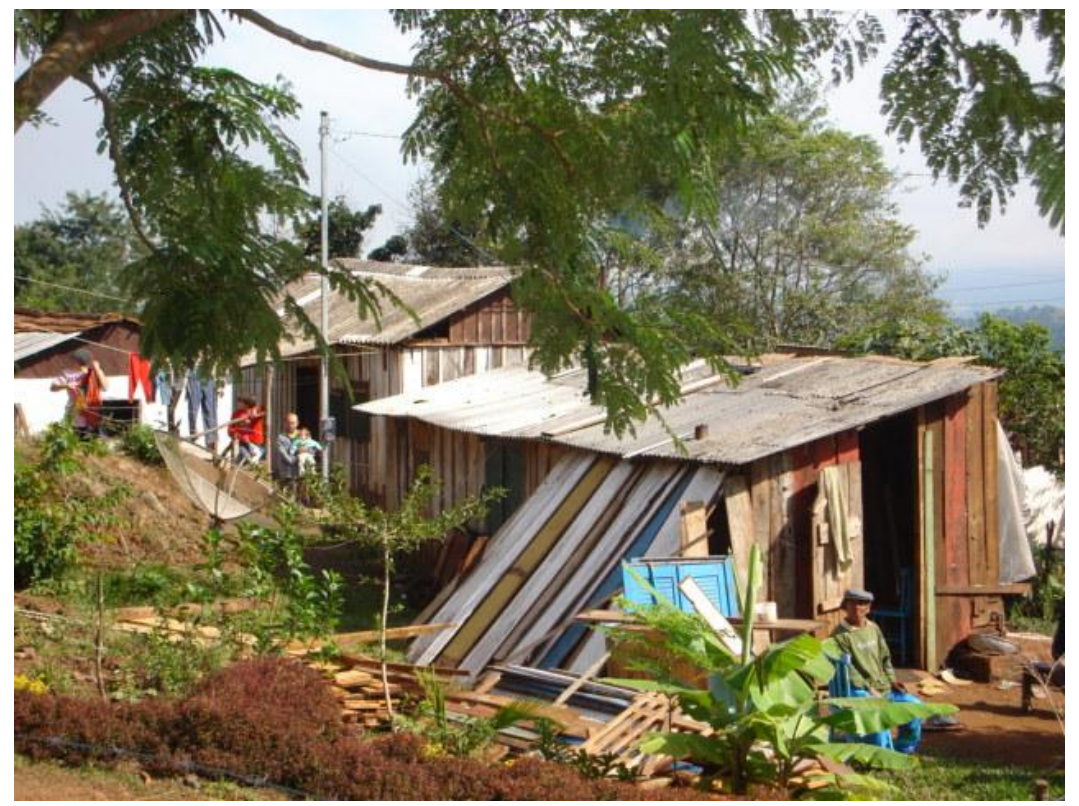

Figura 4: Moradias do aglomerado caboclo da comunidade de Cordilheira. Fonte: Patrício Reichert, 2006.

\section{2- Concentração de caboclos}

É uma determinada área onde reside um maior número de famílias caboclas predominando sobre as famílias teuto-brasileiras, não vivem tão próximos quanto nos aglomerados e as famílias não chegam a ser tão interdependentes entre si, moram dentro de 
seus pequenos lotes entremeados com as famílias de colonos. No território pesquisado foram identificadas duas áreas de concentração cabocla, classificadas em A e B (ver mapa da Localização da População Cabocla Rural de Porto Novo).

\subsection{1 Área A}

Localiza-se dentro da área que compõem as comunidades de Aparecida e Glória, nela se encontram 44 famílias caboclas e 23 mistas. Considerando-se a miscigenação, os traços da etnia cabocla prevalecem sobre a etnia teuto e ítalo-brasileira que também se incluem naquele espaço.

As famílias caboclas ali estabelecidas não apresentam características totalmente homogêneas na forma da sua organização e estruturação sobre a propriedade da terra. Uma e outra propriedade cabocla possui características bastante idênticas a dos colonos, como na infra-estrutura, na forma de organização e tamanho ${ }^{10}$. Uma pequena parcela se encontra na condição de arrendatários ou parceiros em propriedades de colonos. Mas a maioria das famílias são proprietárias de pequenos lotes com uma área inferior a um módulo agrícola (três ha) que adquiriram através de um contrato de compra. Estas geralmente moram nas áreas mais íngremes e impróprias para uma adequada prática agrícola, apesar de praticamente todas terem acesso à energia elétrica, as suas pequenas casas rústicas quase sempre apresentam precárias instalações sanitárias e de água encanada.

Conforme o relato e análise de um antigo colono da comunidade de Aparecida e da pesquisa feita por Jungblut (2000 e 2004), já havia algumas famílias caboclas no local num período anterior a fundação da colônia Porto Novo em 1926. Certamente estas famílias foram atraídas para aquela área como mão-de-obra na extração e contrabando de madeira, e/ou como refugiados de sentenças e de revoltas políticas do Rio Grande do Sul. A partir de 1940 houve o avanço da colonização do noroeste gaúcho até as margens do rio Uruguai, atraídos como mão-de-obra nos serviços da colonização e da extração da madeira nobre pela Volksverein (1940 a 1955), os caboclos desapropriados foram se estabelecendo paulatinamente nesta área, que era a antiga Linha Glória, naquele tempo ainda não ocupado por colonos. Em 1959 se encontravam no lugar, na condição de posseiros, em torno de 97 famílias caboclas, gerando uma situação de grande impasse à colonizadora que pretendia vender os lotes de terra aos colonos embasada na antiga idealização de homogeneidade étnica e religiosa do projeto Porto Novo. 
Na medida em que os colonos adquiriam lotes de terra através da compra e pretendiam se estabelecer na área, passou a haver uma pressão sobre as famílias caboclas para que se retirassem do local. A princípio, os representantes da Volksverein responsáveis pela venda da terra ofereciam os lotes coloniais aos caboclos, já com a certeza de que não teriam condições financeiras para comprá-los. Assim fazia-se a seguinte proposta: “Ou compra ou sai”. Para que os caboclos aceitassem mais facilmente a sua retirada, a Companhia lhes pagava o seu "direito". O irrisório valor em dinheiro seduziu algumas famílias e os fez consentirem com o acordo. Para as famílias que resistiram à proposta, utilizaram a violência através de ameaças por parte de homens da Companhia ou pela repressão policial.

Uma e outra família cabocla teve condições econômicas para adquirir um pedaço de terra da Volksverein, financiando-o a partir da Caixa Rural ${ }^{11}$. A maioria "optou" em seguir a sua antiga prática camponesa a frente das frentes pioneiras, em direção ao sudoeste paranaense, nordeste e norte da Argentina e para o Paraguai. Algumas famílias, na procura de trabalho temporário, passaram a perambular pelas propriedades agrícolas dos colonos de Porto Novo ou de propriedades próximas, durante uma a duas décadas, até que se fixaram como agregados, ou adquiriram um pequeno terreno ou ainda emigraram para outros lugares.

Durante a pesquisa a campo surgiu uma grande dúvida: se no período da desapropriação praticamente todas as famílias se retiraram, por que atualmente a etnia cabocla ainda prevalece em número sobre as demais etnias (teutos e ítalo-brasileiros) que compõem aquela área?

Conforme relatos de antigos moradores, a maioria dos caboclos que atualmente moram na área da antiga Linha Glória, veio do noroeste gaúcho após o período da desapropriação, porque a terra ali era mais barata. Outros são remanescentes das antigas famílias que foram despejadas da sua "terra de direito", depois de vagarem por vários anos entre as propriedades dos colonos na procura de serviços temporários. Retornaram ao local onde haviam deixado suas raízes, agora na condição de arrendatários ou de proprietários de pequenos terrenos geralmente inferiores a um módulo agrícola (três ha).

Apesar da entrada e do retorno de famílias caboclas, a área não voltou a ter a supremacia da etnia cabocla como antes do desfecho da sua desapropriação, no início da década de 60. Na colonização da antiga Linha Glória, a Volksverein não seguiu mais com

\footnotetext{
11 Conforme o relato de antigos moradores calcula-se que não mais de cinco famílias caboclas tiveram condições de comprar um pedaço de terra da Volksverein, atualmente reside nesta área apenas uma destas famílias que naquele tempo havia consigo adquirir um lote de terra da Companhia.
} 
tanto rigor o seu ideal de homogeneidade étnica, vendendo também lotes coloniais a ítalobrasileiros.

Atualmente, as famílias caboclas que conseguiram adquirir um pedaço de terra um pouco maior, sobrevivem como pequenos agricultores, de forma idêntica aos colonos "fracos". Os caboclos agregados também praticam uma pequena agricultura, e de forma paralela muitas vezes ainda se submetem às ordens e aos serviços do seu patrão. Mas a maior parte das famílias caboclas se localiza em pequenos terrenos, quase sempre menores que um módulo agrícola e que foi adquirido por meio de um contrato de compra. Estas sobrevivem de trabalhos temporários nas propriedades dos colonos ou são operárias na agroindústria Seara Alimentos. Na sua pequena área de terra praticam uma reduzida atividade agrícola para complementar a renda familiar, como uma pequena roça, a criação de algumas aves, de um e outro bovino e suíno. Nas famílias onde há um idoso que recebe o benefício da aposentaria, esta chega a ser a principal renda.

Na comunidade de Aparecida e Glória, onde a população cabocla é a maioria e se encontra morando de forma intercalada entre teuto e ítalo-brasileiros, a segregação social do caboclo é menos acentuada do que nas outras comunidades de Porto Novo. Mas ainda persistem preconceitos, ressentimentos e dificuldades de relacionamento entre caboclos e colonos.

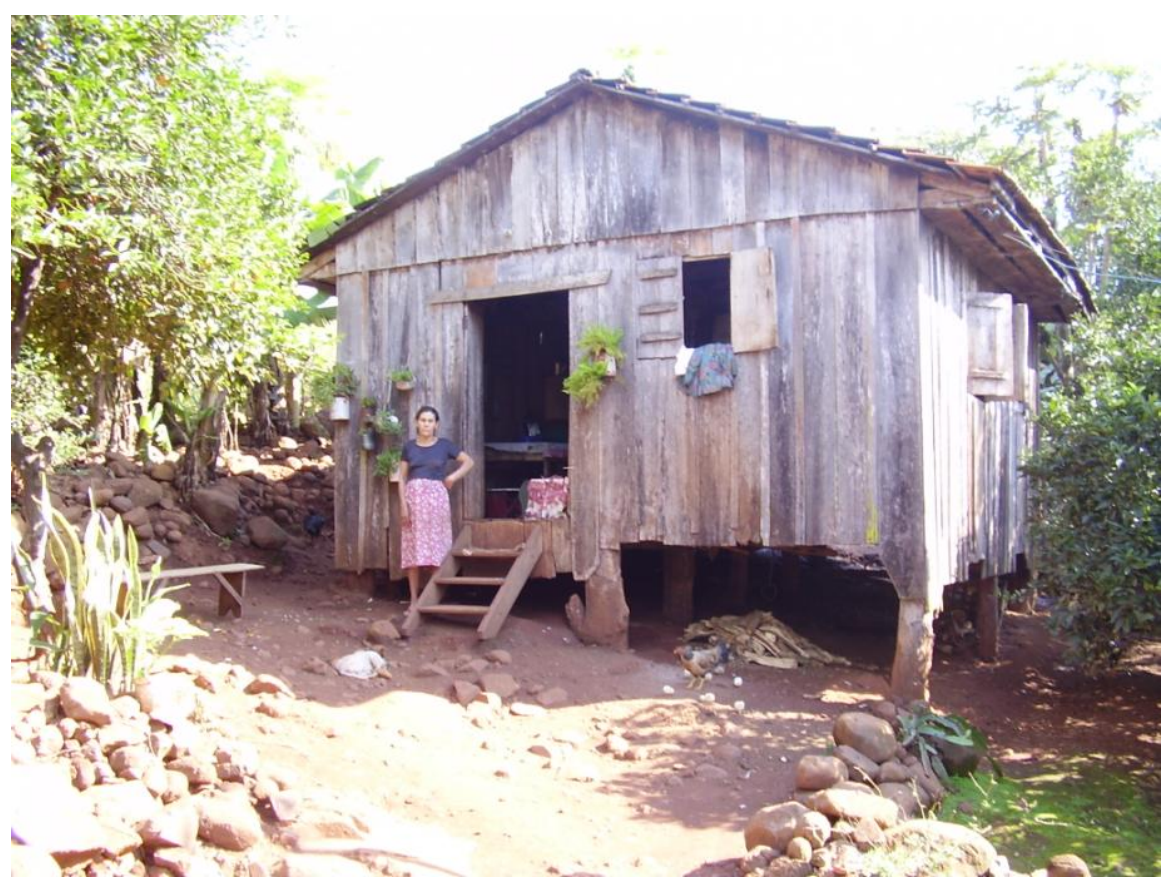

Figura 5: Moradia de uma família cabocla da comunidade de Aparecida. Fonte: Patrício Reichert, 2006 


\subsection{2 Área B}

Abrange uma parte da área da comunidade de São Ludgero e Santo Antônio e ali se encontram 10 famílias caboclas e sete mistas.

Uma pequena parte encontra-se na condição de agregado, enquanto a maioria das famílias são proprietárias de pequenos lotes muitas vezes inferiores a um módulo agrícola. A área na qual estão concentradas as famílias caboclas é bastante íngreme e algumas propriedades têm um difícil acesso. Todas as moradias têm energia elétrica, mas a infraestrutura das propriedades não é homogênea. Algumas famílias possuem uma pequena casa de alvenaria ou de madeira que se apresenta em boas condições, com apropriadas instalações sanitárias e água encanada, ainda tem um galpão, um pequeno estábulo e chiqueiro, um cercado para a pastagem dos bovinos e equipamentos agrícolas (características idênticas da propriedade de um colono "fraco"). Outras famílias, localizadas em seus pequenos terrenos, possuem uma infra-estrutura extremamente precária: suas casas são de madeira, pequenas e rústicas e apresentam uma rudimentar instalação sanitária e de água encanada; junto ao terreno geralmente encontra-se algum chiqueiro ou estábulo toscamente construído; os equipamentos agrícolas são praticamente inexistentes, exceto os mínimos necessários, como facão, foice, enxada e machado.

As famílias que apresentam uma infra-estrutura e tamanho da área de terra maior tiram a maior fonte de renda da sua pequena produção agrícola. As que proprietárias de pequenos terrenos extraem a sua principal renda em trabalhos temporários nas propriedades dos colonos e ainda a complementam nas atividades agrícolas que a reduzida área de terra pode lhes proporcionar: uma pequena roça, a criação de algumas aves, de um e outro bovino ou suíno. Alguns são funcionários da Seara Alimentos e suas famílias conseguem atingir uma renda econômica mais elevada. Novamente é necessário ressaltar a importância do benefício da aposentaria na renda econômica das famílias que possuem algum integrante aposentado.

A área íngreme e imprópria para as práticas agrícolas da região, já no decorrer da colonização era menos valorizada no mercado das terras. A terra barata e a oportunidade de adquirir pequenos terrenos, a partir de lotes coloniais dilacerados pelos "de origem", atraiu as famílias caboclas para o local. A maior parte é remanescente das famílias caboclas que foram desapropriadas na antiga Linha Glória, que depois de perambularem como agregados ou trabalhadores temporários, por vários anos, nas propriedades dos colonos, enfim conseguiram se estabelecer de forma mais definitiva sobre aquela área. Outros são caboclos camponeses imigrados mais recentemente do noroeste gaúcho, após o período da desapropriação (que teve seu desfecho em 1963), atraídos pela possibilidade de adquirirem uma pequena área de terra 
por um preço acessível. É preciso ainda considerar as relações de parentesco, que exercem uma forte influência sobre a escolha do lugar daquele que migra.

As relações de vizinhança parecem bastante recíprocas entre as famílias caboclas e a de colonos "fracos" que se encontram intercalados dentro daquela área e é possível verificar recentes casamentos interétnicos entre estas famílias. A maior parte dos caboclos é católica (enquanto que uma minoria é "crente"), mas tem pouca participação nas atividades religiosas das duas comunidades na qual a área se inclui. Nas atividades sociais recreativas, como futebol, bailes e festas, há uma relativa participação dos caboclos adolescentes e mais jovens, mas estes não chegam a se integrar como sócio no clube social e nem marcam presença em reuniões e trabalhos coletivos. Já os caboclos adultos e idosos preferem permanecer recolhidos em seus lares e praticamente ampliam as suas relações sociais apenas entre caboclos e colonos "fracos" da vizinhança próxima.

Durante a pesquisa a campo, foi possível identificar um forte ressentimento de alguns caboclos em conseqüência das manifestações de preconceitos étnicos por parte dos teutobrasileiros, o que certamente, em grande parte, justifica a sua pouca participação social na comunidade.

\subsection{Famílias caboclas dispersas}

A maior parte destas famílias era num passado mais recente, duas a três décadas atrás, trabalhadores temporários seminômades que migravam de propriedade em propriedade ou moradores dos fundos de uma propriedade de um colono na qual permaneciam estabelecidos por alguns anos. Como estas práticas agrícolas se extinguiram com o processo da modernização agrícola, as famílias caboclas que permaneceram dispersadamente pelo território de Porto Novo, conseguiram fixar-se de forma mais definitiva na condição de agregados ou como proprietários de pequenos lotes de terra. Mas nas suas características camponesas e condições socioeconômicas estas famílias não podem ser homogeneizadas.

Os caboclos na condição de agregados podem ter diferentes acordos com o proprietário da terra. A maior parte dos agregados tem um contrato legal com os proprietários, apenas algumas famílias mantêm acordos não legais por meio de uma relação de confiança, mas estes são cada vez mais raros. Além de a modernização agrícola ter dispensado do meio rural muitos desses caboclos que se encontravam na condição de agregados, atualmente, as leis trabalhistas que trazem maiores direitos a estes camponeses, fazem com que os colonos tenham receio em colocar algum agregado na sua propriedade. 
Quanto aos pequenos lotes de terra das famílias caboclas proprietárias, estes são geralmente localizados em áreas íngremes, com solos desgastados e pedregosos, e ainda, muitas vezes, de difícil acesso. No entanto, estas propriedades não podem ser homogeneizadas, elas variam em tamanho e infra-estrutura. Não ultrapassam a superfície de cinco ha sendo a maioria inferior a um módulo agrícola (três ha) e os terrenos menores medem menos de $1000 \mathrm{~m}^{2}$.

Assim há propriedades (as de maior tamanho) com uma pequena produtividade agrícola onde a família tira dela o seu principal sustento. $\mathrm{Na}$ infra-estrutura, é possível encontrar um pequeno chiqueiro e estábulo, um paiol e implementos agrícolas: um arado, uma carroça, um triturador, uma trilhadeira, entre outros. Pode ter ainda uma pastagem cercada com alguns bovinos, pela qual obtêm uma renda mensal através da produção de leite.

Já as famílias com propriedades inferiores a um módulo vão atrofiando as suas atividades agrícolas em decorrência do tamanho do lote de terra e estão mais dependentes de uma renda externa à propriedade, como trabalhos temporários em diárias e empreitadas ou com vínculo empregatício. A reduzida prática agrícola praticada na propriedade é neste caso uma fonte complementar no sustento familiar.

Por outro lado, as famílias estabelecidas nos pequenos terrenos de cerca de $1000 \mathrm{~m}^{2}$ praticamente não conseguem extrair uma complementação para o seu sustento. A pequena área não possibilita a organização de uma roça e mesmo o alimento para a criação precisa ser adquirido fora da propriedade.

O tamanho do lote de terra necessariamente não é um fator que determina as condições socioeconômicas e de moradia das famílias. Porque em alguns casos, os moradores de pequenos terrenos, possuem vínculos empregatícios (como funcionários da Seara Alimentos, por exemplo) e tem uma renda familiar superior e uma melhor infra-estrutura nas suas casas do que as famílias com uma área de terra superior, e que sobrevivem da pequena produtividade agrícola e de trabalhos temporários. Mas é possível afirmar que de forma geral, as famílias caboclas que estão dispersas no meio rural de Porto Novo, apresentam melhores condições de moradia do que aquelas aglutinadas nos aglomerados.

Estas famílias caboclas, muitas vezes, encontram-se entre as famílias de colonos. Nas relações de vizinhança dão-se melhor com os colonos "fracos", onde há maior reciprocidade, já com os colonos "fortes" as relações quase só se restringem a vínculos de trabalho. Conseguem se integrar às atividades comunitárias quando se submetem completamente às regras estipuladas pelo grupo majoritário teuto-brasileiro, isto quando transmitem simpatia e total confiança e então são considerados guder neger (negro bom). Mas o caboclo assim 
rotulado, em qualquer vacilo nesta representação é excluído do meio social da comunidade. Os caboclos que não conseguem criar boas relações de vizinhança entre os colonos e nem se integrar ao meio comunitário, para não estarem condenados à solidão, buscam relações de convivência com outras famílias caboclas que se encontram além da vizinhança e, muitas vezes, daquela comunidade.

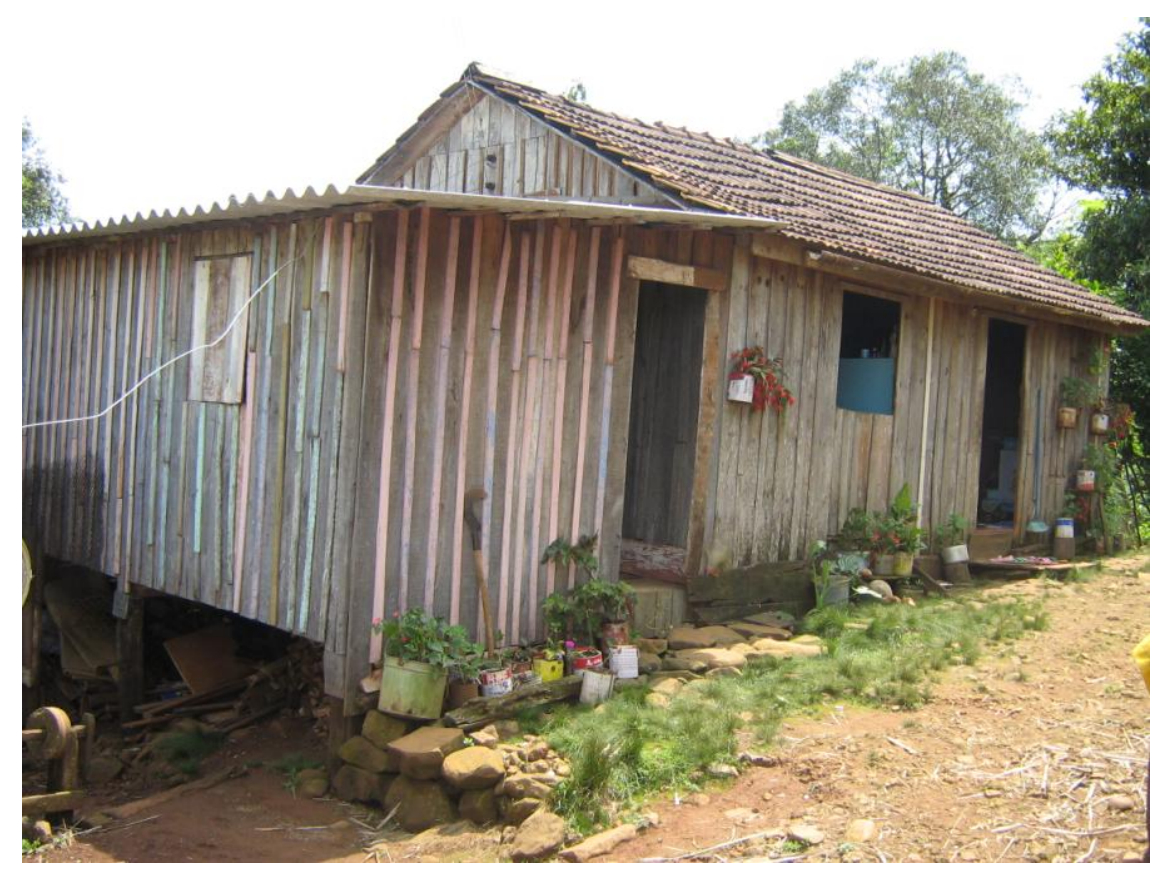

Figura 6: Moradia de uma família cabocla camponesa dispersa. Fonte: Patrício Reichert, 2007

\section{3- A segregação social do caboclo a partir da análise da paisagem urbana}

Com a ampliação da agroindústria e o avanço do processo da urbanização, especialmente a partir da década de 80 , houve uma grande imigração de caboclos para a cidade de Itapiranga ${ }^{12}$, tanto vindos da zona rural de Porto Novo quanto de fora daquele território, principalmente do noroeste gaúcho. Os caboclos que se proletarizaram e/ou incorporam as regras e as exigências do mercado de trabalho conseguiram ascender social e economicamente, enquanto que aqueles que não incorporaram tais qualidades necessárias para uma adaptação ao espaço urbano permaneceram ou até mesmo declinaram na estratificação social.

A dinâmica da cidade de Itapiranga, através do mercado imobiliário, se encarregou de colocar a população cabocla nos diferentes espaços do meio urbano, conforme a posição socioeconômica em que se inserem. "O uso do solo na economia capitalista é regulado pelo

\footnotetext{
12 Entre os três municípios que compõem a antiga colônia de Porto Novo: São João do Oeste, Tunápolis e Itapiranga, o último possui uma maior e mais complexa área urbana.
} 
mecanismo de mercado, na qual se forma o preço desta mercadoria 'sui generis' que é o acesso à utilização do espaço". (SINGER, 1980, p. 78). Assim, uma parcela das famílias caboclas com um maior rendimento econômico mora nos designados "espaços nobres" da cidade, como o centro e áreas específicas de alguns bairros. Já a maior parte da população cabocla, que no geral possuem um poder aquisitivo inferior a maioria dos teuto-brasileiros que ali predominam, concentra-se nas áreas mais periféricas da cidade onde o uso do solo tem um menor valor de mercado e o acesso aos serviços públicos urbanos é menos eficiente.

Para a análise da população sobre a paisagem urbana, dividiu-se o perímetro da cidade de Itapiranga em áreas segundo a intensidade de ocupação desta população. De forma geral, os caboclos que se localizam na diferentes áreas também ocupam lugares diferentes nas atividades produtivas, e se integram mais ou menos intensamente com os teuto-brasileiros e o meio social na qual há a supremacia deste grupo étnico.

\section{Localização da população cabocla na zona urbana de Itapiranga}

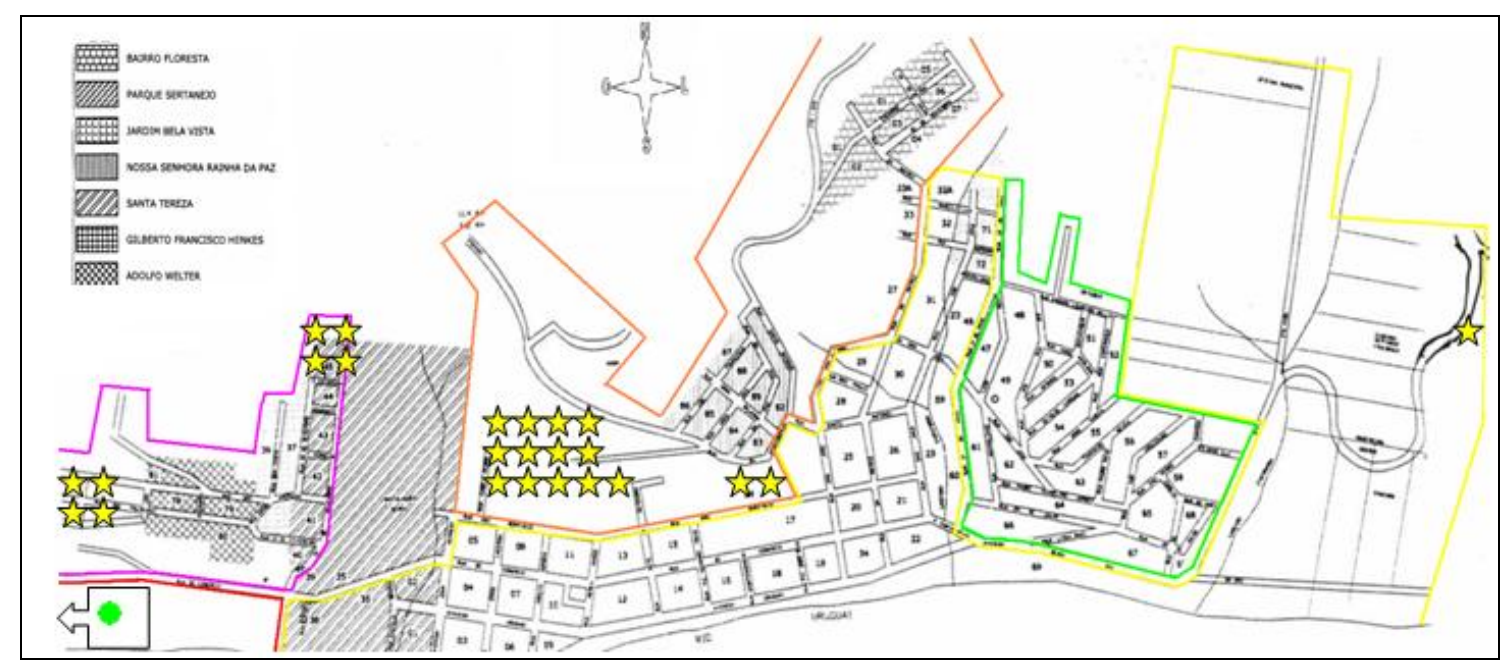

Legenda

Famílias caboclas: $5.6 \%$; mistas: $10.3 \%$

Famílias caboclas: 10,7\%; mistas: 8,7\%.

Famílias caboclas: 15,7\%; mistas: 14,6\%.

Famílias caboclas: $25,1 \%$; mistas: $18,9 \%$.

__ Famílias caboclas: 36,1\%; mistas: 22,9\%.

Figura 7: Fonte: Mapa produzido pelo autor com base no mapa adquirido na prefeitura de Itapiranga. Dados obtidos pelas agentes municipais de saúde que atuam nesta área e da pesquisa in loco.

A partir da análise do mapa pode-se perceber que há uma menor porcentagem de famílias caboclas e mistas nos espaços urbanos mais valorizados pelo setor imobiliário, como o centro e os bairros "nobres" (ver contorno verde, amarelo e laranja). As poucas famílias 
caboclas nestas áreas alcançaram uma maior ascensão social ou podem ser trabalhadores não tão bem remunerados que habitam espaços mais baratos: moradias mais deterioradas e/ou simples, porões de prédios e casas.

As áreas de concentração de famílias caboclas (destacadas no mapa em estrelas amarelas) são espaços mais impróprios para a construção de moradias, portanto, bastante desvalorizados pelo mercado imobiliário. Em alguns casos são ocupados ilegalmente.

As áreas de contorno rosa e vermelho que abarcam a maior porcentagem de famílias caboclas e mistas, chegando a ser predominantes sobre os teuto-brasileiros (porque ali também há uma parcela de ítalo-brasileiros), são os espaços mais periféricos do meio urbano de Itapiranga. O local é denominado de bairro Santa Tereza e se divide em Santa Tereza Alta (contorno rosa) e Santa Tereza Baixa (contorno vermelho).

O grande aumento na porcentagem da população cabocla naquela área, em parte se explica pelo custo mais baixo do espaço urbano, e em outra, porque este local foi intensamente ocupado por caboclos, que vieram principalmente do noroeste gaúcho para se empregarem na agroindústria. As relações de amizade e parentesco fizeram com que os caboclos que imigraram, posteriormente para a cidade de Itapiranga, preferissem se estabelecer neste lugar.

Em Santa Tereza Alta as famílias caboclas intercaladas entre teuto e ítalo-brasileiros, mas concentram-se de forma quase exclusiva em duas áreas mais periféricas. Em Santa Tereza Baixa a população cabocla se concentra, em precárias condições de moradia, ao longo de uma estrada de terra com pouca iluminação pública, que se estende pelas margens do rio Uruguai por um trecho de mata fechada. Os caboclos com melhores rendimentos econômicos ali situados são os que possuem um emprego fixo (funcionários da Seara Alimentos S/A), e a parcela que depende exclusivamente da renda dos trabalhos temporários se mantêm no limite da sobrevivência.

Ainda dentro da área de contorno vermelho, no limite com a zona rural, situa-se a vila São Pedro São Paulo, que pode ser classificada como um aglomerado caboclo. Uma parte destas famílias até 1991 ocupou ilegalmente uma área pública municipal mais centralizada. O poder municipal decidiu utilizar este terreno para a edificação de um educandário e transferiu estas famílias para uma área mais afastada, além do perímetro urbano.

Os caboclos obrigados a se retirarem, a princípio demonstraram um grande descontentamento: "Foi quase um despejo, aconteceu de uma hora para outra, sem aviso, ninguém estava preparado". (caboclo, 65 anos). Na nova área se sentiam abandonados e 
encontrava-se mal instalados nas casas de madeira $5 \mathrm{~m} \times 3 \mathrm{~m}$ construídas pela prefeitura, que não tinham instalações sanitárias, água encanada e nem energia elétrica.

A partir de 2002, as condições de moradia da população da vila São Pedro São Paulo melhorou significativamente. A prefeitura fez um loteamento na área, instalou uma rede de água e energia elétrica e construiu casas de alvenaria com grande parte do material arrecadado de doações feitas pelo comércio e pela indústria. Os moradores da vila auxiliaram com a mãode-obra na construção. Além das famílias que já estavam estabelecidas, a prefeitura inseriu ainda outras famílias carentes (e por sinal caboclas) no projeto, o que totalizou a construção de 14 pequenas casas de alvenaria.

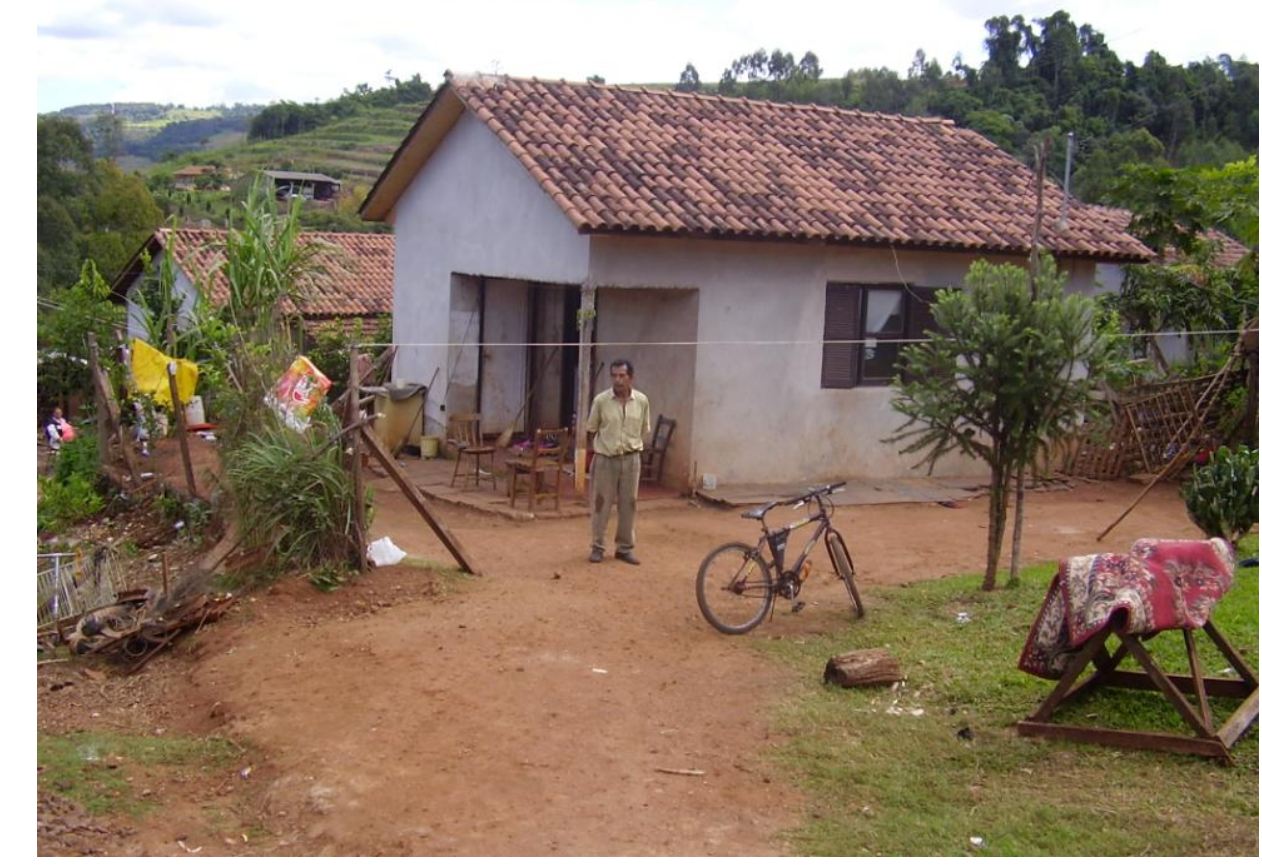

Figura 8: Moradia de uma família cabocla da Vila São Pedro São Paulo. Fonte: Patrício Reichert, 2006

Apesar de terem as suas condições de moradia melhoradas, estas famílias no geral, permanecem entre as piores situações econômicas da população de Porto Novo. A parcela mais bem sucedida é sempre aquela que tem algum emprego fixo. Mas uma grande parte mantém uma renda mínima e imprevisível, sobrevivendo dos serviços temporários. Durante a pesquisa a campo foi possível verificar que alguns destes caboclos deslocam-se para o centro da cidade, mais especificamente no calçadão da Avenida Uruguai, onde permanecem à disposição de quem os queira para a execução de um eventual trabalho. Aquele que necessita de uma mão-de-obra temporária sabe que ali vai ter uma oferta disponível. Quem mais oferece serviço a estes caboclos é o comércio de material de construção, no carregamento e descarregamento de caminhões. 
Ao se fazer uma análise sobre a paisagem urbana da cidade de Itapiranga é possível verificar que a população cabocla ocupa mais intensamente os espaços mais desvalorizados pelo mercado imobiliário. Nas áreas em que o uso do solo urbano é mais caro, além de haver uma extrema queda na densidade populacional cabocla, a intensidade da mestiçagem é bem maior, como pode se verificar nas áreas de contorno verde e amarelo. Tal fato revela que a integração social e o casamento interétnico acontecem com mais facilidade entre caboclos e teuto-brasileiros quando se aproximam na estratificação social. Quando indivíduos das duas etnias se assemelham na condição socioeconômica se identificam nos hábitos culturais (acaboclamento ou no ateutoamento), ou ainda, quando ambos incorporam de forma equivalente os valores do atual mercado econômico capitalista. Mas mesmo que a integração e a mestiçagem aumentem, quando se aproximam da mesma classe social, os caboclos continuam vítimas de preconceito, porque o medo do diferente se tornar igual também é um fator que aumenta o preconceito étnico-racial. (CHNAIDERMAN, 1996, p. 85):

A manifestação dos preconceitos em conseqüência da ameaça do diferente se tornar igual e se revela principalmente na competitividade do mercado econômico capitalista. Durante a pesquisa a campo isso foi muito visível entre os teuto-brasileiros funcionários da Seara Alimento S/A, que acusaram de preguiçosos, oportunistas e incompetentes, os seus colegas de trabalho caboclos.

\section{Considerações Finais}

O projeto de colonização Porto Novo idealizado na construção de um território étnico e religiosamente homogêneo: católicos e alemães; segregou desde o inicio da sua formação a população cabocla, uma minoria étnica que sempre desempenhou papéis importantes na transformação do espaço geográfico da colônia.

O processo da modernização agrícola segregou ainda mais o caboclo ao desqualificar a sua mão-de-obra. Ao observar-se a paisagem do antigo território de Porto Novo percebe-se a segregação social da população cabocla, tanto no meio rural quanto no urbano, segregado por fatores econômicos e de preconceitos étnico-raciais.

No meio rural os caboclos aglutinam-se em aglomerados dentro de pequenas áreas de terra, concentram-se em espaços mais inóspitos e impróprios para a agricultura ou vivem isoladamente entre os camponeses teuto-brasileiros como agregados ou proprietários de pequenos terrenos. As pequenas áreas de terra que ocupam não lhes propiciam a subsistência, assim, buscam a sua sobrevivência oferecendo a sua mão-de-obra numa agricultura moderna que os descarta quase que por completo. 
No meio urbano a população cabocla encontra-se nos espaços mais periféricos e grande parte sente dificuldade em se integrar ao mercado de trabalho formal. A parcela que busca se qualificar e adaptar as novas exigências trabalhistas é vítima do preconceito que se forma com o medo do diferente se tornar igual.

\section{Referências}

BERQUE, Augustin. Paisagem-marca, paisagem-matriz: Elementos da problemática para uma geografia cultural. Tradução: Ednês M. Vasconcelos Ferreira e por Anne-Marie Milon Oliveira. In: CORRÊA, Roberto Lobato; ROSENDAHL, Zeny (Orgs.). Paisagem, tempo e cultura. 2. ed. Rio de Janeiro: EdUERJ, 2004.

CLAVAL, Paul. A geografia cultural. Tradução: Luiz Fugazzola Pimenta, Margareth de Castro Alfeche Pimenta. 2. ed. Florianópolis: Ed. da UFSC, 2001.

A paisagem dos geógrafos. Tradução: Márcia Trigueiro. In: CORRÊA, Roberto Lobato; ROSENDAHL, Zeny (Org.). Paisagens, textos e identidade. Rio de Janeiro: EdUERJ, 2004.

CHNAIDERMAN, Miriam. Racismo, o estranhamente familiar: uma abordagem psicanalítica. In: SCHWARCZ, lilia Moritz; QUEIROZ, Renato da Silva (Orgs.). Raça e diversidade. São Paulo: Editora da Universidade de São Paulo: Estação Ciência: Edusp, 1996.

DUNCAN, James. A paisagem como sistema de criação de signos. Tradução: Márcia Trigueiro. In: CORREAA, Roberto Lobato; ROSENDAHL, Zeny (Org.). Paisagens, textos e identidade. Rio de Janeiro: EdUERJ, 2004.

JUNGBLUT, Roque. Documentário histórico de Porto Novo. São Miguel do Oeste:Arco Íris \& Editora, 2000.

Porto Novo: Um documentário histórico. 2 ed. Itapiranga: Edições SEI; FAI, 2004.

SEMPRINI, Andrea. Multiculturalismo. Tradução: Laureano Pelegrin. Bauru: EDUSC, 1999.

SINGER, Paul. O uso do solo urbano na economia capitalista. Boletim paulista de geografia. São Paulo, AGB, n. 57, 1980, p. 77-92. 